\title{
Editorial
}

\section{COLÉGIO INVISÍVEL NA SOCIEDADE EM REDE}

\begin{abstract}
$\Lambda$
comunicação científica é fundamental para o desenvolvimento da ciência, na medida em que possibilita $o$ compartilhamento das pesquisas e a geração de novos conhecimentos. Os pesquisadores têm necessidade de compartilhar com seus pares os resultados de suas suas investigações por variados motivos, dos quais destacamos a legitimidade de sua pesquisa e o prestígio em seu campo de atuação.

Essa comunicação, conforme Meadows
\end{abstract} (1999) ocorre a partir de dois canais principais de comunicação: formais e informais. Pelos canais formais circulam informações relacionadas à pesquisas já finalizadas ou em fase final, ou seja, pesquisas que já são consideradas prontas para serem tornadas públicas. Nesse caso, as informações circulam através de livros, periódicos e eventos científicos.

Os canais informais se caracterizam como um meio através do qual circulam informações que geralmente fazem parte de pesquisas em andamento, que ainda precisam ser finalizadas. Nesse sentido, os canais informais são fundamentais para que os pesquisadores possam confirmar ideias, rever abordagens, processos e métodos em seu fazer científico. Nesses canais as informações circulam através de encontros informais, e-mails e redes sociais de pesquisa, formando o que se convencionou chamar de Colégio Invisível.

Price (1976) registra no século XVII os primeiros encontros de cientistas em um clube de Londres. Nesses encontros, onde se discutiam questões das ciências naturais e de filosofia de maneira informal, foram importantes para a criação da Royal Society. Esses encontros informais de cientistas discutindo temáticas específicas de pesquisa foram importantes para o desenvolvimento da ciência.

O Colégio Invisível é um elemento importante no processo de comunicação científica, pois propicia um espaço para troca de informações sobre pesquisas em andamento. E se no passado foram constituídos por grupos com poucos participantes, atualmente, com o advento das tecnologias digitais de informação e comunicação, observam-se grupos com grande número de participantes, que se tornam cada vez mais visíveis na sociedade em rede. Destacamse, dentre outras, as redes de pesquisadores, como a ResarchGate, os blogs, como o SciElo em Perspectiva, e os microblogs ambientados no Twitter.

Nesse sentido podemos até pensar, como fizeram Wersig e Neveling (1975) com relação à informação, que atualmente há uma nova relevância para um fenômeno antigo: o Colégio Invisível. Ou, mesmo, dizer, como fizemos em um editorial sobre a literatura cinzenta, que na sociedade em rede os colégios invisíveis se iluminam na web.

Gustavo Henrique de Araújo Freire Isa Maria Freire Editores

\section{REFERÊNCIAS}

FREIRE, G. H. de A.; FREIRE, I. M. A literatura cinzenta se ilumina na web. Informação \& 
Sociedade: Estudos, v.25, n.2, p. 5-6, maio/ago. 2015.

MEADOWS, A.J. A comunicação científica. Brasília, DF. : Briquet de Lemos, 1999.
PRICE, Derek J. Solla. O desenvolvimento da ciência: análises histórica, filosófica, sociológica e econômica. Rio de Janeiro: Livros Técnicos e Científicos, 1976.

WERSIG, G., NEVELING, U. The phenomena of interest to information science. The Information Scientist. v.9, n.4, 1975. 